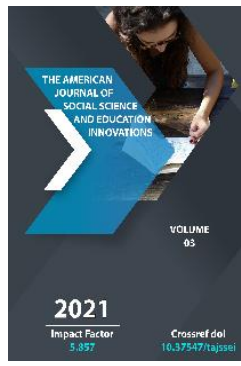

Journal Website: http://usajournalshub.c om/index,php/tajssei

Copyright: Original content from this work may be used under the terms of the creative commons attributes 4.0 licence.

\section{Teaching English To Medical Students On The Basis Of Professionally Oriented Approach}

\author{
Dilfuza Yuldasheva \\ Senior Lecturer Of Namangan State University, Uzbekistan \\ Yodgora Tuhtaboyeva \\ Master's Students Of Namangan State University, Uzbekistan \\ Maftuna Shamsiddinova \\ Master's Students Of Namangan State University, Uzbekistan
}

\title{
ABSTRACT
}

Modern approaches such as professionally oriented, communicative and competence-based approaches in teaching a foreign language are core issues for all areas of higher education today. One of the areas of teaching English for the specialty is English for medical purposes. English for medical purposes is taught from a real-world perspective, which means teaching English is context-specific and vocabulary in many countries around the world. This article deals with issues of the teaching students of medical specialties in English for special purposes and provides a brief overview of the specific characteristics of medical English and exercises aimed at mastering at professional vocabulary acquisition in mixed-level learning groups.

\section{KEYWORDS}

English language, teaching medical student, English for special purposes, medicine.

\section{INTRODUCTION}

Modern approaches such as professionally oriented, communicative and competence- based approaches in teaching a foreign language are core issues for all areas of higher 
education. One of the areas of teaching English for the specialty is English for medical purposes. In accordance with the above approaches, the goal of teaching English to medical students is to develop their ability to use a foreign language for professional and personal communication and for continuous self-development. English for medical purposes is taught from a real-world perspective, which means teaching English is context-specific and vocabulary in many countries around the world. But more importantly, teaching medical English should be focused on the development of communication skills, problem solving and decision making. At the end of the ESP course, students should be able to understand professionally oriented texts about the latest developments in their field, practice and improve their speaking and writing skills, write scientific articles, participate in exchange programs and international scientific events. In other words, students must master functional language (standard phrases for communicating with patients, counseling, writing emails, etc.), language skills and systems [1].

\section{MATERIALS AND METHODS}

The need for future doctors to master the English language is due to two factors: the dynamic nature of the medical field of scientific knowledge and the tendency to establish ties between different states, which involve communication and exchange of experience among medical workers and the speakers of different languages. Doctors from different countries understand each other through Latin which is widely used in writing. However, today the priority of the English language is as a tool for live communication with foreign language colleagues. In addition, knowledge of the English language allows future and current specialists to learn and to read the results of the latest research in the field of medicine, published in authoritative foreign publications and databases, such as Science Direct, Web of Science, PubMed, Google scholar, Eric and etc. For medical students, there are many opportunities to participate in academic mobility programs that provide internships and exchange studies abroad. Therefore, the content of the course for teaching students English for medical purposes can cover the following aspects:

$>$ Verbal communication with patients and colleagues;

> Written communication on professional topics (filling out medical records, issuing referrals to specialists, writing incident reports, filling out other medical documentation);

Reading scientific texts on medical topics;

Presentation of reports and presentations at conferences.

To increase the efficiency of the learning process, work with students can be based on both domestic and well-proven foreign textbooks. The manuals, developed by domestic authors for medical faculties, allow students to form the lexical and grammatical basis, skills of working with a special text; provide knowledge about anatomy, physiology and pathological processes, methods of their diagnosis and treatment, but to a lesser extent use communication skills that are important when working with patients focused on the development of the skills of communicating with colleagues, patients and their families, 
often on complex and medical issues. The learning process should be organized to improve both medical knowledge of students and their language skills in practical communication situations [2]. Medical English has a number of characteristics:

$>$ The prevalence of the times of the Simple (Past, Present) in the description of processes, mechanisms, functions of body systems (Practically all absorption takes place in the small intestine; The wall of the pharynx and the superior part of the esophagus, and the tongue and the soft palate all contain striated muscle tissue), collecting and clarifying information about current complaints and the patient's condition (Where do you get the pain? Does the pain spread anywhere else? Does it wake you up at night?), filling out a medical history (When did the pain start? When did the attacks first come on?). Present Perfect is required to describe the onset of a painful condition (Have you ever had coughing attacks like this before? Has anyone in your family ever had an illness like this as far as you are aware?);

$>$ The prevalence of the passive voice (The needle is inserted; The patient is sedated to induce drowsiness);

$>$ The presence of phrasal verbs (When did the attacks first come on? Is there anything that brings it on? Try to get into a routine for taking medication if you can);

$>$ The predominance of nouns over verbs. A significant part of nouns of Latin and Greek origin have non-standard forms of plural formation (nucleus-nuclei, fascia-fasciae, vertebra-vertebrae,

bronchus-bronchi, cilium-cilia).

The most striking distinguishing feature of medical English is the presence of a specific vocabulary, the study and mastery of which is one of the most important directions in the process of teaching and learning a foreign language to students. [5]

Situations: doctor - doctor, doctor - head of the clinic (employer), doctor - supervisor, doctor conference organizer, doctor - editor of the journal;

Topics: grant, resume, motivation letter, business letter, conference abstracts, presentation, speech, research article, correspondence with the editor, strategies for teaching writing and speaking;

Grammar grammatical constructions characteristic of the oral and written communication style on the subject;

Forms and methods of discussion, "brainstorming", learning in collaboration, mini projects, business and role-playing games, simulation of situations;

Professional and academic vocabulary;

Professional and academic vocabulary should be introduced in context, for example, in specialty texts, which will allow students to learn the environment of the new lexical unit (phrases or grammatical structures associated with it). The meanings of new words can be represented through direct translation, the use of pictures, definitions, a set of synonyms, antonyms and subject terms. 
To familiarize students with medical vocabulary, to practice and consolidate it, a variety of tasks are used, such as labeling the bones of the skeleton; label the organs of the digestive system, matching terms and definitions, filling in the gaps in sentences and in the text, matching medical terms with their household equivalents (intestine - gut, bowel, chicken-pox - varicella, pertussis -whooping cough, to biopsy - to take a tissue sample, herpes simplex - cold sore, the urinary system waterworks), classification of diseases and symptoms and etc.

A certain difficulty for the teacher in the process of teaching students is presented by mixed groups with initial differences in the level of language competence of students. In terms of student academic performance, this is not an ideal environment, but on the other hand, students, as they get used to differences in language proficiency, learn from their peers and become more tolerant of different cultures and educational systems. Since students in such groups, based on the initial level of proficiency in the target language and individual differences, may find the content of the educational material boring because of its ease or, conversely, the difficulty of assimilation, the teacher's task is to find ways to involve each student in the learning process. ... For example, we can vary the difficulty of an activity that requires students to mark up a particular drawing or diagram. Less advanced students can get visual reference in the form of a list of terms that they can use in this assignment. Stronger students can be asked to mark the drawing without supporting words and phrases. In communication exercises, less prepared students can be helped to build utterances by providing them with support on a specific grammatical structure and vocabulary, while more advanced learners have greater freedom in choosing how to format their speech.

Thus, a mixed learning environment, while being cognitively and emotionally challenging, is capable of developing invaluable social skills of students, such as tolerance towards people with less or more knowledge and skills in English.

\section{CONCLUSION}

In conclusion, we note that the content of the ESP course for medical students should be focused on developing and activating professional and academic skills and abilities and form the necessary universal competencies. Upon completion of the course, students should be able to understand and apply medical terminology, discuss and present professional information, read, understand and produce medical texts of various orientations, as well as be aware of the responsibility for learning for their further development. The acquired skills will allow them to be more confident and competitive in situations related to communication in academic and professional spheres, achieve great success in their career and become good specialists not only in Uzbekistan, but also at the international level.

\section{REFERENCES}

1. Lodhi M. A., Shamim M., Robab M., Shahzad S. H., Ashraf A. English for doctors: an ESP approach to needs analysis and course design for medical students // International Journal of English Linguistics. 2018. No. 8. P. 205-214. DOI:10.5539/ijel.v8n5p205 
2. Neskina S.A. Teaching reading and professional communication as the goal of foreign language training for specialists of a non-linguistic university // Niva Povolzhya. 2008. No. 3 (8). S.91-94.

3. McCarter S. Oxford English for careers: Medicine 1. Oxford University Press, 2009.143 p.

4. Saville-Troike, M. (2006). Introducing Second Language Acquisition. Cambridge: Cambridge University Press.

5. Anthony, L. (1997). "ESP. What does it mean?" ON. CUE. Retrieved from http: // www.interserver.miyazakimed ac.jp/cue/pc/anthony.htm

6. Chomsky, N. Aspects of the theory of syntax [Electronic resource]. - http://biblook.ru/guman-ok/01-1498.php

7. Hutchinson, T., Waters, A. (1987). English for specific purposes: a learning centered Approach, Cambridge University Press. Cambridge 